\title{
Community participated management of chaur (floodplain) fisheries: A case study of mahisar chaur in Samastipur district of Bihar, India
}

\author{
Raushan Kumar, Nalini Ranjan Kumar* and Manoj Kumar \\ Central Institute of Fisheries Education (CIFE), Versova, Mumbai- 400061 (MS), INDIA \\ *Corresponding author. E-mail: nrkumar@cife.edu.in
}

Received: January 22, 2015; Revised received: July 20, 2015; Accepted: December 2, 2015

\begin{abstract}
Mahisar chaur, situated in north-eastern part of Samastipur district of Bihar, is spread over 607.29 ha area with an average water depth of 2.5-3 m. The chaur was flood prone and remained inundated with water for most part of the year and hence was not suitable for agriculture. With collective efforts of land owners, a drainage canal along with sluice gate was constructed to manage the flow of water in the chaur to take up both the agriculture and fishery enterprises in the chaur. Now the chaur is being successfully utilized for fishery by a cooperative society of land owners during the period of water logging (June/July to October) and for agriculture, by individual farmers during November to April. The present study investigated into income and employment generation and management practices of chaur (floodplain) in Samastipur (Bihar), India for suggesting suitable measures to improve production and productivity from the resource. For the purpose, primary data was collected from 60 sample respondent by personal interview method with the help of pre-tested questionnaire specially designed for the study. Fishery and agriculture was the two enterprises undertaken by land owners in the chaur. During rainy season when entire chaur is inundated with water fisheries is practised with community participation while agriculture is practiced during rabi season by individual farmers on their land holdings. Cropping intensity in chaur was 199.05 percent which indicate about two time use of same area for different economic activity. The overall net income from both the agriculture and fishery in chaur was INR 43,041.94 (US\$ 791.08) per hectare per annum and employment generation was 78.11 man days per hectare per annum. The contribution of agriculture in total income was 69.52 percent while that of fisheries was 30.48 percent. Retention of water in central part of the chaur for rearing of juveniles caught during draining out of chaur may improve fish productivity which in turn may increase income and employment opportunity and share of fisheries in total income.
\end{abstract}

Keywords: Community, Floodplain, Management of Chaur, Pre- harvest contractor

\section{INTRODUCTION}

Chaurs (floodplains) are shallow transitional land, highly productive for both agriculture and fishery (Islam, 2003). Floodplains locally known as chaurs in Bihar, India, are major fisheries resources and measure about 45,978 ha, mainly found in the basins of KosiGandak river systems of North Bihar (Govt. of Bihar, 2008). However, despite such natural resources and fish as highly preferred food item, aquaculture and open water fisheries resource remain highly underutilized (Govt. of India, 2008). The river Gandak and Koshi (along with its tributaries) have the distinction of nurturing huge number of seasonal common property water resources (chaurs). The Mahisar chaur, situated in north-eastern part of Samastipur district, is spread over 607.29 ha area with an average depth of 2.5-3 m. This is being utilised collectively by land owners for fishery and individually for crop cultivation. The chaur is owned by more than 1000 farmers of four villages namely Bhiraha east, Bhiraha west, Bhiraha south and Haripur who have their land holdings in the chaur.
The chaur is a pan shaped flood plain in the vicinity of Kareh river, a tributary to Koshi river. Before 1936, the chaur was getting inundated with water during June/July to September with $2.5-3.0 \mathrm{~m}$ of water and 0.8 - $1.0 \mathrm{~m}$ of water during September to January every year. Due to which, it was not possible to take up any agricultural crop in the chaur area. This water logging in the chaur rendered land owners of the chaur practically landless which also affected the labourers of the area badly as they were not getting work for earning their subsistence. Visualizing the gravity of situation, Indian Government constructed a bund across entire length of the Kareh river in 1930s. Sluice gates were also installed at several places to drain out the runoff water from upland to avoid unwanted water logging. However, the situation of the chaur remained the same. An innovative farmer of the village took initiative to organise the farmers, mainly youths, of the villages of the chaur area into a co-operative known as Yuvak sangh in 1936 for the construction of drainage canal (Surhula baha) to regulate the flow of water into chaur utilizing the sluice gate. The regulation of flow of water into chaur area allowed farmers to take up 
agricultural crops individually on their land during rabi season and fishery in the chaur collectively during rainy season (kharif season). All the farmers, on whose lands channel was constructed donated their land to the Yuvak sangh.

Since construction of the drainage channel, the chaur is getting drained successfully every year on time to enable farmers to grow rabi crops in their respective lands and harvest bumper yield. The main crop of the chaur is wheat which is grown in over more than $85.82 \%$ area. Other crops grown in the chaur are gram, lentil and sugarcane. The fishes of the chaur are sold by the sangh to pre-harvest contractor in an open auction who is bound to drain the chaur in October month of the year. The income generated is used for the restoration of the drainage channel and for the welfare of the villagers of all the four villages. The chaur is being utilized for both the agriculture and fishery purposes that provide income and employment to farmers, fishers and daily wage earners.

The floodplains/wetlands need to be institutionalized by establishing controlling and management institutions (Marothia, 2002). But, due to fluctuating nature of fisheries resources and being extreme prone to floods, it is a challenging task. The research across the globe suggests the community participation in management and community-based institutions had succeeded in such situations (Hanna, 1998). Therefore, the efforts should be made to establish community based institutions and management system for sustainable utilizations of chaurs. Since, the chaur is being successfully utilised for the fishery through community as well as agriculture through individual farmers since long, it is imperative to study the model for further advocacy. Therefore, the present study is an attempt to investigate into economics and management of Mahisar chaur. The findings of the study will help in taking appropriate decision for the development of chaur in the state of Bihar.

\section{MATERIALS AND METHODS}

The primary data for the study was collected from selected sample respondents by personal interview method with the help of pre-tested questionnaire specially designed for the study. The sample farmers/ fishers for the study were selected following the multistage stratified random sampling technique in all the

Table 1. Cropping pattern on sample farms in Mahisar chaur.

\begin{tabular}{lll}
\hline Particulars & $\begin{array}{l}\text { Area } \\
\text { (ha) }\end{array}$ & $\begin{array}{l}\text { Percentage to net } \\
\text { sown area (\%) }\end{array}$ \\
\hline Wheat & 98.27 & 85.01 \\
Mustard & 11.13 & 9.63 \\
Others & 5.11 & 4.42 \\
Fisheries & 115.6 & 100.00 \\
Cropped Area & 230.11 & 199.06 \\
Net Sown Area & 115.6 & 100.00 \\
Cropping intensity (\%) & 199.057 & \\
\hline
\end{tabular}

four villages using methodology describe in Cochran (1977). For the purpose of estimating income and employment generation and understanding the management of chaur, discussion with Farmers, District Fisheries Officer, Fisheries Extension Officer, president, secretary and member of the yuvak sangh was conducted. A total of 60 respondents were selected, comprising of 29 farmers, 10 artisanal fishers, 1 preharvest contractor, 12 members of yuvak sangh and 8 officials of Department of fisheries, Government of Bihar during 2012-13.

Cost and return for chaur fishery and various agricultural crops like wheat, mustard, gram, and sugarcane were estimated and compared following the method described by Salim and Biradar (2001). To evaluate economic feasibility of agricultural crops and fishery, benefit-cost ratio (BCR) was computed as per Gittinger (1982). With a purpose to compare income and employment generated from agriculture and fishery, income and employment generated in all the agricultural crops were averaged and multiplied with the cropping intensity to get income and employment generated per hectare. The average income and employment from fishery was estimated by dividing the total production from capture fishery with the entire area of the chaur to get the average income and employment per hectare from chaur area.

\section{RESULTS AND DISCUSSION}

Cropping pattern affects cost and profitability of the farm and varies from farm to farm and place to place. The cropping pattern prevalent on sample farms was estimated and presented in Table 1. The cropping intensity on sample farm was 199.1 per cent. The moderate cropping intensity in the chaur indicates that the area under chaurs are being used during both the rabi season for agriculture and Kharif season for fisheries. Wheat was the major crop cultivated on 85.01 percent of cropped area followed by mustard (9.63\%) and other like, Lentil, gram and sugarcane (4.42\%). Since agricultural crops and fishery were the economic activities being taken in chaur, economics of chaur depends on both the agriculture and fishery enterprises, and hence economics of both the enterprises have been estimated separately and presented in subsequent sections..

Economics of agricultural crops produced in chaur: The cost and return of all the agricultural crops were estimated and presented in Table 2.Perusal of the table revealed that wheat was the major crop of the chaur, which was cultivated on 85.8 per cent of the total chaur area. Net return from wheat cultivation was highest, INR 30,519 (US\$ 560.93) per hectare with a BCR of 1.81. The variable cost accounted for 62.2 per cent of total cost and rest 37.8 per cent was accounted by fixed cost. Among variable costs, cost of labour was largest component sharing for 36 percent of total variable cost followed by cost of fertilizers (31 per 
Table 2. Cost and returns from various agricultural crops on sample farms.

\begin{tabular}{|c|c|c|c|c|c|c|c|c|}
\hline Particulars & Wheat & & Mustard & & Others & & Overall & \\
\hline A. Variable Cost & $(₹ / \mathrm{ha})$ & (\$/ha) & $(₹ / h a)$ & (\$/ha) & $(₹ / \mathrm{ha})$ & (\$/ha) & $(₹ / \mathrm{ha})$ & (\$/ha) \\
\hline Seed & 2033.93 & 37.38 & 220.44 & 4.05 & 2530.33 & 46.51 & 1879.82 & 34.55 \\
\hline Fertilizer & 7265.4 & 133.53 & 5597.48 & 102.88 & 2941.29 & 54.06 & 6910.32 & 127.01 \\
\hline Irrigation charges & 1617.97 & 29.74 & 1208.93 & 22.22 & 1510.24 & 27.76 & 1573.41 & 28.92 \\
\hline Machine Hiring & 3407.36 & 62.62 & 3227.76 & 59.32 & 809.79 & 14.88 & 3273.99 & 60.17 \\
\hline Labour Cost & 8437.9 & 155.08 & 7648.29 & 140.57 & 11322.86 & 208.11 & 8489.89 & 156.04 \\
\hline Miscellaneous & 581.75 & 10.69 & 544.03 & 10.00 & 859.1 & 15.79 & 590.46 & 10.85 \\
\hline Interest on working capital & 198.19 & 3.64 & 157.36 & 2.89 & 225.45 & 4.14 & 195.44 & 3.59 \\
\hline Total Variable Cost & 23542.5 & 432.69 & 18604.29 & 341.93 & 20199.06 & 371.24 & 22913.32 & 421.13 \\
\hline B. Fixed Cost & & 0.00 & & 0.00 & & 0.00 & & 0.00 \\
\hline Depreciation & 1056.71 & 19.42 & 1092.41 & 20.08 & 967.57 & 17.78 & 1056.2 & 19.41 \\
\hline Interest on fixed capital & 958.02 & 17.61 & 1075.77 & 19.77 & 843.75 & 15.51 & 964.37 & 17.72 \\
\hline Repair \& Maintenance & 311.61 & 5.73 & 280.14 & 5.15 & 309.47 & 5.69 & 308.46 & 5.67 \\
\hline Land Rent & 11965.19 & 219.91 & 12029.99 & 221.10 & 12020.55 & 220.93 & 11973.96 & 220.07 \\
\hline Total Fixed Cost & 14291.53 & 262.67 & 14478.31 & 266.10 & 14141.34 & 259.91 & 14302.98 & 262.88 \\
\hline C. Total Cost & 37834.03 & 695.36 & 33082.6 & 608.03 & 34340.4 & 631.15 & 37216.3 & 684.01 \\
\hline D. Revenue & & 0.00 & & 0.00 & & 0.00 & & 0.00 \\
\hline Total production $(\mathrm{kg})$ & 4928.16 & 4928.16 & 1753.23 & 1753.23 & 2054.72 & 2054.72 & 4491.34 & 4491.34 \\
\hline Price $(₹ / \mathrm{kg})$ & 13.87 & 0.25 & 34.34 & 0.63 & 28.67 & 0.53 & 14.95 & 0.27 \\
\hline Gross Income & 68353.58 & 1256.29 & 60205.92 & 1106.54 & 58908.82 & 1082.70 & 67140.18 & 1233.99 \\
\hline E. Net Income & 30519.55 & 560.93 & 27123.32 & 498.51 & 24568.42 & 451.55 & 29923.88 & 549.98 \\
\hline F. BCR & 1.81 & 1.81 & 1.82 & 1.82 & 1.72 & 1.72 & 1.8 & 1.8 \\
\hline
\end{tabular}

Table 3. Cost and return from fishery in Mahisar chaur.

\begin{tabular}{|c|c|c|c|c|c|c|}
\hline \multirow{2}{*}{$\begin{array}{l}\text { Particulars } \\
\text { A. Variable Cost }\end{array}$} & \multicolumn{2}{|c|}{ (Pre-Harvest Contractor) } & \multicolumn{2}{|c|}{ Artisanal Fishers } & \multicolumn{2}{|c|}{ Overall Fishery } \\
\hline & $(₹ / h a)$ & (US\$/ha) & (₹/ha) & (US\$/ha) & $(₹ / \mathrm{ha})$ & (US\$/ha) \\
\hline Labour Cost & 1575.03 & 28.95 & 1321.44 & 24.29 & 2896.47 & 53.24 \\
\hline Miscellaneous & 1419.4 & 26.09 & 667.51 & 12.27 & 2086.91 & 38.36 \\
\hline Interest on working capital & 221.06 & 4.06 & 111.82 & 2.06 & 332.88 & 6.12 \\
\hline Total Variable Cost & 3215.49 & 59.10 & 2100.77 & 38.61 & 5316.26 & 97.71 \\
\hline \multicolumn{7}{|l|}{ B. Fixed Cost } \\
\hline Depreciation & 329.17 & 6.05 & 1448.85 & 26.63 & 1778.02 & 32.68 \\
\hline Interest on fixed capital & 287.38 & 5.28 & 1175.73 & 21.61 & 1463.11 & 26.89 \\
\hline Land Rent & 6092.64 & 111.98 & 0 & 0.00 & 6092.64 & 111.98 \\
\hline Repair \& Maintenance & 24.09 & 0.44 & 171.49 & 3.15 & 195.58 & 3.59 \\
\hline Total Fixed Cost & 6733.28 & 123.75 & 2796.07 & 51.39 & 9529.36 & 175.14 \\
\hline C. Total Cost & 9948.77 & 182.85 & 4896.84 & 90.00 & 14845.62 & 272.85 \\
\hline \multicolumn{7}{|l|}{ D. Revenue } \\
\hline Total production $(\mathrm{kg} / \mathrm{ha})$ & 164.93 & 3.03 & 78.88 & 1.45 & 243.81 & 4.48 \\
\hline Selling Price $(₹ / k g)$ & 101.87 & 1.87 & 64.27 & 1.18 & 89.71 & 1.65 \\
\hline Gross Revenue & 16801.42 & 308.80 & 5069.62 & 93.18 & 21871.04 & 401.97 \\
\hline E. Net Income & 6852.65 & 125.95 & 172.77 & 3.18 & 7025.42 & 129.12 \\
\hline F. B:C Ratio & 1.69 & 1.69 & 1.04 & 1.04 & 1.47 & 1.47 \\
\hline
\end{tabular}

cent). Mustard was the second most popular crop cultivated in the chaur. Net return from the mustard cultivation was ₹27,123 (US\$ 498.51) per hectare and BCR 1.82. Variable cost constituted about 56 per cent of total cost and 44 percent was shared by fixed cost. Among variable cost, cost of labour was the major cost accounting for about 41 per cent of total variable cost followed by cost of manures and fertilizers (30 per cent). A number of other crops like lentil, gram and sugarcane were also being cultivated in the chaur. The average net return from other crops was ₹24,568 (US\$ 451.55) per hectare with BCR of 1.72 . Overall net return from agricultural crops was ₹29,923 (US\$ 549.98) per hectare with a BCR 1.80 . The variable cost was the major contributor of expenditure (61.5 per cent) out of which labour cost was the major contributor followed by cost on fertilizer and manures.

Economics of chaur fishery: Mahisar chaur is riverfed and inundate with water during flood season. In the chaur, capture fishery is in practice where fish and fish seed enter into chaur from Kareh river through sluice gates while filling the chaur with river water during the month of June/July. By closing the sluice gate, managing committee ensure longer duration of stay of water to provide longer duration for fishes to grow and drains it out in October for growing rabi crops. Fishing remain unrestricted till the auction of chaur for all the artisanal fishers residing in the vicinity of the chaur by employing simple gears like gill net and traps without paying anything to land holders. However, after auction of chaur in month of August, pre-harvest contractor restrict the fishers from fishing. The chaur is harvested by the contractor with the help of fishers, while draining out the chaur. The chaur gets drained out in 25-30 days by the end of October and get dried up in next 10-15 days by mid of November. After drying up of chaur, farmers grow rabi crops in their respective land.

Cost and return for capture fishery for both kinds i.e. 
Table 4. Employment generation from agriculture and fishery in the chaurs.

\begin{tabular}{lrrr}
\hline Enterprise & \multicolumn{1}{l}{$\begin{array}{l}\text { Family } \\
\text { Labour }\end{array}$} & \multicolumn{1}{l}{$\begin{array}{l}\text { Hired } \\
\text { Labour }\end{array}$} & $\begin{array}{l}\text { Total } \\
\text { Labour }\end{array}$ \\
\hline Agriculture & 4.65 & 55.19 & 59.84 \\
Fishery & 0.00 & 18.27 & 18.27 \\
Overall & 4.65 & 73.46 & 78.11 \\
\hline
\end{tabular}

Table 5. Income distribution among the different stakeholders.

\begin{tabular}{llll}
\hline Stakeholders & $\begin{array}{l}\text { Income } \\
(\cdot / / h a)\end{array}$ & $\begin{array}{l}\text { Income } \\
(\mathbf{U S} \mathbf{\text { ha }})\end{array}$ & $\begin{array}{l}\text { \% } \\
\text { Income }\end{array}$ \\
\hline Farmers & & & \\
(a) Agriculture & 29923.88 & 549.98 & 69.5 \\
(b) Fisheries & 6092.64 & 111.98 & 14.2 \\
(c) Total & 36016.52 & 661.96 & 83.68 \\
2. Artisanal Fishers & 172.77 & 3.18 & 0.4 \\
3. Pre Harvest Contractor & 6852.65 & 125.95 & 15.92 \\
Total Income & 43041.94 & 791.08 & 100 \\
\hline
\end{tabular}

Table 6. Income and employment generation from the chaur.

\begin{tabular}{llll}
\hline Particulars & Agriculture & Fishery & Overall \\
\hline Income $(₹ / h a)$ & 29923.88 & 13118.06 & 43041.94 \\
& $(69.52)$ & $(30.48)$ & $(100.00)$ \\
Income (US\$/ha) & 549.98 & 241.10 & 791.08 \\
Employment (man & 59.84 & 18.27 & 78.11 \\
days/ha) & $(76.61)$ & $(23.39)$ & $(100.00)$ \\
\hline
\end{tabular}

Note: Figures in parenthesis indicate percentage of respective figure to overall

before auction (artisanal fishers) and after auction (preharvest contractor) was estimated separately and presented in Table 3. The productivity of the chaur was 243.81 kilogram per hectare per year. Chandra et al. (2010) found average fish production of 2920.43 kilogram per hectare per year from beels of Bangladesh whereas production from the chaurs was 243.81 kilogram per hectare per year, indicates poor management of capture fishery in chaurs of Bihar in comparison to Bangladesh. It was also observed that the size of captured fishes were small, which indicates the existence of potential to increase the yield from chaur by extending the period of rearing of juvenile fishes. Since source of seed in chaur is only through river water, sufficient number of fish seed required to be stocked as suggested by Jha and Chandra (1997) to get optimum yield from the chaur.

The net average profitability of the pre-harvest contractor was ₹6,852.65 (US\$ 125.95) with BCR 1.69 whereas artisanal fishers were fishing with a nominal profit of ₹172.77 (US\$ 3.18) per hectare per year. The overall net income from the chaur fishery was ₹7025.42 (US\$ 129.12) with BCR 1.47. The Variable cost was 35.8 per cent of total cost which is contradictory to the estimate of Jha (2009), who estimated higher percentage of variable cost $(54.5 \%)$ in the total cost of fish cultivation in flood prone area of Bihar. It may be mainly due to absence of seed stocking in case of Mahisar chaur. Labour cost was also very less as harvesting was done during draining out the chaur only. Fixed cost $(64.2 \%)$ was the major component of total cost out of which land rent was the major one.

Income and employment generation from agriculture and fishery: Agriculture and fishery both are labour intensive and generate ample employment opportunities. In the study area most of the agricultural and fishery activities were carried out on contract basis. To estimate employment of human labours in man days, contractual charges for labour work was divided by the minimum wage rate declared by government of Bihar for the Agricultural year 2012-13 and are presented in the Table 4. Labour absorption in agriculture (59.84 man days per hectare) was substantially higher than capture fishery (18.27 man days per hectare). The total employment generated from chaur area was 78.11 man days per hectare per annum out of which 94.05 per cent was for hired labour. Employment generation from fishery was very poor mainly due to the fact that in Mahisar chaur, fishery demands less managerial inputs resulting in farmers spending little of their time on management, supervision and making arrangements for fish harvesting.

Income distribution among different stakeholders namely farmers, artisanal fishers and pre-harvest contractor in Mahisar chaur are given in the Table 5. The share of farmers, artisanal fishers and pre-harvest contractor for chaur fisheries was 83.68 percent, 0.40 percent and 15.92 percent in total income generated from chaur. Income and employment generation vary from enterprise to enterprise. The net return from both the agriculture and fishery in chaur was ₹43,041.94 (US\$ 791.08) per hectare per year. The contribution of agriculture and fishery in chaur income were 69.52 per cent and 30.48 per cent respectively (Table 6). It is also clear that net return generated from agriculture was higher than fishery in the chaur. The overall employment generation in chaur from both the agriculture and fishery enterprise was 78.11 man days per hectare per year out of which about 76.6 percent was contributed by agriculture and only 23.4 percent was from fishery (Table 6). The share of fisheries in total income and employment may be improved by adopting improved package of practices suggested for the enhanced fisheries in such resource.

Thus both the agriculture and fishery component were playing important role in generating income and employment opportunities for different stakeholders depending on chaurs for their livelihood. Hence there is need to give due weightage to both the enterprises for optimal harnessing of potential of chaur in economic development of the region. It was observed that a large number of juveniles were also caught while fishing in the chaur which are of no use. The same can be reared in small portion of chaur for fish production from the resource. This will also improve the share of fisheries in total income and employment from the chaur.

Community participated management of chaur fishery: During the month of late June or early July either due to flood in the Kareh river or opening up 
sluice gate on request of the Yuvak sangh, the chaur gets sufficient river water. The river water enters into the chaur. With many of the brood fish, fry, and fingerlings enter into the chaur as the shallow water area of chaur act as the breeding and feeding ground for them. As soon as, the water level of Kareh river starts declining the sangh request the irrigation department to close down the sluice gate. This ensures water retention for longer period in the chaur area. This not only enhances the productivity of the chaur but also clean up the land mass from weeds which ultimately decreases the cost of field preparation for agricultural crops. During the last week of September or first week of October the sangh again requests the irrigation department to open the sluice gate to drain out the water of chaur. Harvesting of fishes is done by installing 4 to 5 stagnant trawl net (locally known as bore jal).

The sangh sells fishes to pre-harvest contractor at lump sum amount through open auction. The auction amount for the chaur for the year 2012 was ₹37 lakhs (US\$68003.57). The pre-harvest contractor harvest the fish during September to October for 25-30 days while draining out the chaur. The Yuvak sangh which manages fishery in Mahisar chaur has three layers management structures:

i. Core committee/office bearer- The core committee is a 3 members committee elected by general body of the society to take up day to day decisions to run the sangh activities and maintain account of the sangh and arrange meetings, etc. The sangh is headed by president who is assisted by one secretary and a treasurer which forms core committee. The main function of the core committee is to take decisions whereas working committee is the active body of the society which facilitate the auction and help in decision making.

ii. Working committee- General body of the sangh elects 9 members for a period of 5 years as working committee to facilitate smooth functioning of the society. The decision of the sangh is taken once all the members of working committee agree for the same. In case of opposition even by a single member of the working committee, the decision cannot be taken.

iii. General body- Any member of the four villages irrespective of their caste and creed who attain 18 years of age can become member of general body by paying membership fee to the society.

In general, 2-4 GBM (General body meeting) are arranged in a year. Any additional need based meeting can also be organised by the working committee on short notice. The source of income for the sangh is the money received from auctioning of fish of Mahisar chaur. The income is primarily used for upkeep of the drainage channel (Surula baha) and the rest amount is spent on other social activities. The sangh has been taking up various activities for the welfare of society such as education, social, religious, sports, road construction, and health etc. The sangh is provides subsidies for water pump and tubewells for agriculture pur- poses in the chaur area. The sangh has established a library in the village, contributed in construction of school, temple etc. During health hazard, causality or any epidemic, the sangh has contributed actively for free of cost drug distribution or financial help. The decisions to spend the amount are taken by the working committee only if all the members agree for the same.

Conflicts: Conflict exists when individuals who depend on each other express different views, interests, or goals and perceive their views as incompatible or oppositional. There exist a conflict between farmers and fishers for fishing rights in the chaur. Some portion of the canal, in river after sluice gate (towards river), is property of Government of Bihar. Fishing is practiced while draining out of the chaur in this government owned portion of canal. As per the Government of Bihar, 2006 the government water body should be leased out to fishers co-operative only. So, fishers demand for leasing out the canal to them whereas Yuvak sangh claim that fishes are being produced in chaur which is owned by farmers and hence they have the right on fishes of the chaur and harvesting those fishes even in government canal. For a period of 3 years during 2003-05, Government of Bihar had leased the government owned portion of canal to fishers co-operative. However, in 2006, the right was transferred to Yuvak sangh and now, the case is pending in court for decision and fishing right is with Yuvak sangh, the farmer's cooperative. Leasing of the canal by government to fishers will increase the cost of fishing as farmers of the chaur will be forced to harvest fish in the chaur, a very large area, and hence will increase inefficiency in fish production in the chaur. The conflict can be sorted out with understanding the problem in depth by government officials and helping both the parties in resolving their conflict. Co- Management of such resource where all the stakeholders in the properties including government play a role in the management of resource may go a long way in resolving the conflict as well as better utilisation of such resource. Noble (2000) has also suggested that co-management played an important role in fishery development and conflict management. Co-management is a process of management in which government shares power with resource users, with each given specific rights and responsibilities relating to information and decisionmaking.

\section{Conclusion}

Chaurs have tremendous potential for development of capture, culture and culture-based fishery. The present study concluded importance of resource in economic life of human being and potential for income and employment generation through agriculture and fishery activities, it is imperative to harness its potential for the economic development of underdeveloped region of the country. On the basis of findings of the study, following can be suggested for the development of 
chaur fishery in Bihar

Community participated management of Mahisar chaur is successful in utilising the chaur resource for both the agriculture and fisheries which has provided ample employment opportunities as well as income to land owners as well as land less fishers and wage earners and hence can be adopted in other areas for the utilisation of the vast resource available in form of chaur. Though the Mahisar chaur is being managed profitably, there is scope for further improvement in it by avoiding growth overfishing and rearing the caught juvenile up to table size fishes. While draining out of the chaur, water should be retained in the lower most part of the chaur for rearing of juvenile fishes caught during the harvest. If it is not then, there should be ban on fishing with fine meshed gears and traps to enable the juveniles to re-enter into the river for further growth which will add to fish productivity in the river.

\section{ACKNOWLEDGEMENTS}

The authors are thankful to Dr. W.S. Lakra, Director, Central Institute of Fisheries Education (CIFE), Mumbai-61, India for constant encouragement and providing necessary facilities for the study.

\section{REFERENCES}

Chandra, K.J., Sarkar, D., Khaleque, M.A. and Das, D.R. (2010). Economic analysis of floodplain aquaculture at Dandkandi upzilla in Comilla, Journal of Bangladesh Agricultural University 8(2). ISSN 1810-3030:323-332.

Cochran, William G. (1977). Sampling Techniques ( $3^{\text {rd }}$ Edition), Willey Eastern Limited, New Delhi, pp 89-96.

Gittinger, J.P. (1982). Economic analysis of Agricultural Projects, $2^{\text {nd }}$ edn. The John Hopkins University Press,
Baltimore and London, pp 361.

Government of Bihar (2006). Bihar Fisheries Jalkar Management Bill, 2006. Animal and Fisheries Resources Department, Government of Bihar, pp 4-11.

Government of Bihar (2008). Draft Fisheries Policy, Directorate of Fisheries, Department of Animal and Fish Resources , Government of Bihar. Downloaded from http://ahd.bih.nic.in/acts/ar-01-20-06-2008.pdf

Government of India (2008). Bihar's Agriculture Development: Opportunities \& Challenges -A Report of the Special Task Force on Bihar. Downloaded from the website-http://planningcommission.gov.in/aboutus/ taskforce/tsk_adoc.pdf

Hanna, S. (1998). Co-Management in SmallScale Fisheries : Creating Effective Links among Stakeholders. International CBNRM Workshop, Washington, D.C.

Islam, M. (2003). Bio-economic Development of Floodplains: Farming versus Fishing in Bangladesh. American Agricultural Economics Association meeting, Montreal, Canada, July 27-30.

Jha, B.C. and Chandra K. (1997). Kusheshwarsthan Chaur (North Bihar) Status and prospects for fisheries development, Bull.No. 71 Central Inland Capture Fisheries Research Institute (Indian Council of Agricultural Research) Barrackpore 743101 West Bengal.

Jha, U.M. (2009). Economics of fish farming in flood prone areas of Bihar with special reference to Kosi river system. Vide F.No.0-15012/49/05 SER, pp 91-93.

Marothia, D.K. (2002). Institutionalizing Common Pool Resources, Concept Publishing Company, New Delhi. Nath. D. 2004. Majuli Island - an introduction. Majuli Festival. Majuli Festival Committee, Majuli.

Noble, B.F. (2000). Institutional criteria for co-management. Marine Policy, 24: 69-77.

Salim, S.S. and Biradar, R.S. (2001). Practical manual on Fisheries project formulation and management. Central Institute of Fisheries Education, pp 26-28. 